\title{
Getting your Report Seen in and Beyond ABE\&M
}

The "Arquivos Brasileiros de Endocrinologia \& Metabologia" - ABE\&M hosts a variety of investigational experiences and reviews from the most prestigious endocrinologists from Brazil and abroad through different journal sections. However, its visibility worldwide has just begun.

Initial steps towards ABE\&M modernization and expansion are on track. Now, the current editorial team is taking further efforts mostly improving the interface among the journal board, authors, and reviewers, such as the online whole-article access (Epub ahead of print, available at our homepage), fully electronic paper submission and peer-review processes.

Since the last couples of years, ABE\&M has been exchanging more with the international community, counting on authors, readers, and collaborators overseas. Conceivably, in the same way that many native-language poets were introduced to a larger number of poetry lovers throughout the world, by removing language-issue stones from their paths, we opted to entirely edit this issue in English as a first stone-removing step forward to be more supportive and competitive in the biomedical literature. That being so, let's move on in this path regardless the stones we will relentlessly remove from our road.

"Never should I forget that in the middle of the road there was a stone,

There was a stone in the middle of the road, In the middle of the road there was a stone"

Carlos Drummond de Andrade, by Elizabeth Bishop and Emanuel Brasil (editors) in An Anthology of Twentieh-Century Brazilian Poetry (1).

Therefore, growing efforts were taken in order to gather more publications. We are confident that attracting original articles will improve ABE\&M's scientific contribution and visibility among other endocrine journals available online. And we can achieve that by reporting relevant well-investigated endocrine cases to fulfill larger number of readers and authors' expectation.

In addition, we do believe we can contribute to the medical literature exploring clinical- and molecular-related approaches by learning from case reports with different presentation and of helpful clinical outcome. In fact, many breakthroughs in Endocrinology field were initially presented as case reports, and were subsequently followed by the identification of their genetic cause years latter, as we may historically recall Carney complex $(2,3)$, thyroid hormone resistance $(4,5)$, multiple endocrine neoplasia type 1(6-9), and maturity-onset diabetes of the young $(10,11)$, for instance.

This current issue pooled interesting experiences in conducting patients with several endocrine diseases, and so was named as "Clinical \& Molecular Endocrine (C\&M) Case Reports" Special Edition. These first 30 invited articles were selected and peer-review guided by Edna Kimura (Editor-in-chief),

\section{editorial}

\section{MAgnus R. DIAS DA SILVA}

Adjunct Professor in the Department of Biochemistry, Federal University of Sao Paulo, Escola Paulista de Medicina. Co-Editor of Brazilian Archives of Endocrinology and Metabolism (ABE\&M). Laboratory of Molecular Endocrinology 
Berenice Mendonca (invited co-editor) and me. For them, I am eternally grateful. We welcome you to get the best of the following selected C\&M readings.

\section{REFERENCES}

1. Bishop E, Brasil E. An anthology of twentieh-century Brazilian Poetry Canada: Wesleyan University; 1972. Bishop E, Brasil E, eds.

2. Carney JA, Hruska LS, Beauchamp GD, Gordon H. Dominant inheritance of the complex of myxomas, spotty pigmentation, and endocrine overactivity. Mayo Clin Proc. 1986;61(3):16572.

3. Rees JR, Ross FG, Keen G. Lentiginosis and left atrial myxoma. Br Heart J. 1973;35(8):874-6.

4. Refetoff S, DeWind LT, DeGroot LJ. Familial syndrome combining deaf-mutism, stuppled epiphyses, goiter and abnormally high PBI: possible target organ refractoriness to thyroid hormone. J Clin Endocrinol Metab. 1967;27(2):279-94.

5. Sakurai A, Takeda K, Ain K, et al. Generalized resistance to thyroid hormone associated with a mutation in the ligandbinding domain of the human thyroid hormone receptor beta. Proc Natl Acad Sci U S A. 1989;86(22):8977-81.
6. Agarwal SK, Kester MB, Debelenko LV, et al. Germline mutations of the MEN1 gene in familial multiple endocrine neoplasia type 1 and related states. Hum Mol Genet. 1997;6(7):1169-75.

7. Underwood LE, Jacobs NM. Familial Endocrine Adenomatosis. a Family with Hyperinsulinism as the Predominant Manifestation. Am J Dis Child. 1963;106:218-23.

8. Wermer P. Genetic aspects of adenomatosis of endocrine glands. Am J Med. 1954;16(3):363-71.

9. Zollinger RM, Ellison EH. Primary peptic ulcerations of the jejunum associated with islet cell tumors of the pancreas. Ann Surg. 1955;142(4):709-23; discussion, 724-8.

10. Tattersall RB. Mild familial diabetes with dominant inheritance. Q J Med. 1974;43(170):339-57.

11. Yamada S, Zhu Q, Aihara $Y$, et al. Cloning of cDNA and the gene encoding human hepatocyte nuclear factor (HNF)-3 beta and mutation screening in Japanese subjects with maturityonset diabetes of the young. Diabetologia. 2000;43(1):121-4.

\section{Correspondence to:}

Magnus R. Dias da Silva

Rua Três de Maio, 100

04044-020 São Paulo SP

E-mail: magnus.bioq@epm.br 